\title{
Effects of grilling on cholesterol oxide formation and fatty acids alterations in fish
}

\author{
Efeito do cozimento na formação de óxidos de colesterol e alteração da composição de ácidos graxos em peixes
}

\author{
Tatiana SALDANHA ${ }^{1}$, Neura BRAGAGNOLO ${ }^{2 *}$
}

\begin{abstract}
Due to the adverse effects of the cholesterol oxidation products for the human health, the search of the occurrence and the quantification of these compounds in foods are considered of great importance. In this paper the effect of grilling in hake and sardine on cholesterol oxides formation and fatty acids alterations was investigated. The main fatty acids determined in both fishes were docosahexaenoic (DHA), oleic, eicosapentaenoic (EPA) and palmitoleic. The total lipids, fatty acids and cholesterol contents were decreased significantly $(\mathrm{p}<0.02)$ after thermal treatment, with simultaneous increase of the cholesterol oxides contents. The cholesterol oxides determined in both species in the present study were: 19-hydroxycholesterol, 24(S)-hydroxycholesterol, 22(S) hydroxycholesterol, 25-hydroxycholesterol, 25(R)-hydroxycholesterol and 7-ketocolesterol. Besides the presence of the cholesterol oxides in raw fishes, there were a greater number of products resulting from the oxidation of cholesterol side chain, a fact rarely observed in foods.
\end{abstract}

Keywords: hake; sardine; fatty acids; cholesterol; effect of grilling; HPLC.

\section{Resumo}

Devido aos efeitos adversos dos produtos de oxidação do colesterol, a ocorrência e quantificação destes compostos em alimentos são consideradas de grande importância à saúde pública. O objetivo do presente trabalho foi verificar o efeito do cozimento em pescada e sardinhas na formação de óxidos de colesterol e alteração da composição de ácidos graxos. Os principais ácidos graxos determinados nas duas espécies de pescados foram: docosahexaenoico (DHA), oleico, eicosapentaenóico (EPA) e palmitoleico. Os teores de lipídios totais, ácidos graxos e colesterol diminuíram significativamente $(\mathrm{p}<0.02)$ após o tratamento térmico, com simultânea elevação das concentrações dos óxidos de colesterol. Os óxidos determinados no presente estudo mostraram-se comuns as duas espécies de peixes: 19-hidroxicolesterol, 24(S)-hidroxicolesterol, 22(S)-hidroxicolesterol, 25-hidroxicolesterol, 25(R)-hidroxicolesterol e 7-cetocolesterol. Além da presença de óxidos de colesterol em peixes frescos, observou-se um maior número de produtos originados a partir da oxidação da cadeia lateral do colesterol, fato raramente observado em alimentos.

Palavras-chave: pescada; sardinha; ácidos graxos; colesterol; efeito do cozimento; HPLC.

\section{Introduction}

Regular consumption of fish is recommended in view of its high content of omega-3 PUFA, especially eicosapentaenoic acid (EPA) and docosahexaenoic acid (DHA). These compounds have been reported to prevent certain diseases, especially cardiovascular and inflammatory disorders, cancer, and stroke (DIN; NEWBY; FLAPAN, 2004).

Lipids can undergo alterations during food preparation with consequent decrease in the nutritional value. Lipid oxidation is one the major reactions affecting the fatty acid composition and cholesterol and originating cholesterol oxidation products (COPs) or cholesterol oxides. Cholesterol oxides are of clinical interest especially due to their association with atherogenesis, cytotoxicity, inflammatory process, rheumatic arthritis, mutagenesis, carcinogenesis, and degenerative diseases such as Parkinson and Alzheimer. COPs also impair the membranes function, which results in the alteration of their permeability (SCHROEPFER, 2000).

The degree of oxide formation in food systems is related to processing temperature, heating time, storage conditions, level of activation, and packing conditions. The nature, proportion, and degree of unsaturation of fatty acids present in animal products will indicate the approximate susceptibility of cholesterol oxides formation, particularly in fish products rich in omega-3 PUFA (OHSHIMA, 2002).

Fish is normally grilled in a variety of ways before consumption. Grilling causes a protein denaturation, which can lead to the loss of antioxidant enzyme activity or the release of catalytically-active iron from metallo-proteins, disruption of cells membranes, which bring polyunsaturated fatty acids in contact with pro-oxidants, and thermal decomposition of hydroperoxides to pro-oxidants species, such as alkoxyl and

Recebido para publicação em 16/4/2008

Aceito para publicação em 3/1/2009 (003404)

Departamento de Ciências de Alimentos, Faculdade de Engenharia de Alimentos, Universidade Estadual de Campinas - UNICAMP, CEP 13083862 Campinas - SP, Brasil,

E-mail: neura@fea.unicamp.br

${ }^{2}$ Departamento de Ciência de Alimentos, Universidade Estadual de Campinas - UNICAMP, Campinas - SP, Brasil

${ }^{*}$ A quem a correspondência deve ser enviada 
hydroxyl radicals (HUR; PARK; JOO, 2007). These radicals will accelerate the chain reaction of lipid oxidation including cholesterol. Thus, grilling leads to significantly increased oxidation, as reflected by COPs formation.

Some authors reported the presence of cholesterol oxides in processed fish (AL-SAGHIR et al., 2004; OHSHIMA et al., 1996; SALDANHA; BRAGAGNOLO, 2008; SAMPAIO et al., 2006; SHOZEN et al., 1995), however, information about the presence of these compounds in fresh fishes is scarce. Thus, the objective of this study was to verify the alterations in the fatty acid composition and formation of cholesterol oxides in raw and grilled popular fish species consumed in Brazil.

\section{Materials and methods}

\subsection{Chemicals}

Cholesterol and cholesterol oxides standards 19hydroxycholesterol (19-OH), 20- $\alpha$-hydroxycholesterol (20 $\alpha-\mathrm{OH})$, 22 "R"-hydroxycholesterol (22R-OH), 24"S"-hydroxycholesterol (24S-OH), 22 "S"-hydroxycholesterol (22S-OH), 25hydroxycholesterol $(25-\mathrm{OH}), 5,6 \alpha$-epoxycholesterol $(\alpha-\mathrm{EP})$, $5,6 \beta$-epoxycholesterol ( $\beta$-EP), 25 "R"-hydroxycholesterol (25R-OH), 7-ketocholesterol (7-keto), 7 $\beta$-hydroxycholesterol $(7 \beta-\mathrm{OH})$, and $7 \alpha$-hydroxycholesterol $(7 \alpha-\mathrm{OH})$ were purchased from Sigma (Milford, MA, USA) and Steraloids (Newport - RI, USA). Nonadecanoic methyl ester was purchased from Sigma (St. Louis - MO, USA) and the fatty acids standard mixture was purchased from Supelco ${ }^{\text {TM }} 37$ (FAME Mix 18919, Bellefonte, PA, USA). The purity of the standards varied from 95 to $98 \%$. HPLC grade $n$-hexane and 2-propanol were obtained from Mscience (Darmstadt, Germany), and all other analytical grade solvents were obtained from Merck (Darmstadt, Germany).

\subsection{Samples}

Fresh Brazilian sardines (Sardinella brasiliensis) and Atlantic Hake Fillets (Merluccius hubbsi) were purchased from local market in the city of Sao Paulo. One kg of each fish was washed and divided into 2 lots; half was grilled and the other half was analyzed raw. The sardines were eviscerated and filleted. The hake fillets were thawed and cut lengthwise. The fishes were grilled under $175^{\circ} \mathrm{C}$ for two minutes on each side until reach an internal temperature of $75 \pm 1^{\circ} \mathrm{C}$. The temperature was monitored manually using a digital calibrated thermometer (Traceable Long-Stem, Friendswood, TX, USA). The samples were ground and homogenized in a multiprocessor (Mega Master, RI 3170, 500 W, Sao Paulo, Brazil) to obtain homogeneous dough. The experiment and the analyses were carried out in duplicate $(n=4)$.

\subsection{Methods}

The moisture content was determined according to Association of Official Analytical Chemists (2000). The lipids were extracted and determined according to Bligh and Dyer (1959) method.

The lipids (25 mg) obtained by Bligh and Dyer (1959) method were converted into methyl esters according to
Joseph and Ackman (1992) to determine the fatty acids using a gas chromatograph (Varian 3400CX, Walnut Creek, CA, USA), equipped with a split injector (1:50) and a flame ionization detector, and a workstation. The chromatographic separation was achieved on a fused silica CP-SIL 88 capillary column $100 \mathrm{~m} \times 0.25 \mathrm{~mm}$ i.d., $0.20 \mu \mathrm{m}$ film thickness (Chrompack, Middelburg, The Netherlands) according to procedures and conditions previously reported (SALDANHA; BRAGAGNOLO, 2007). The temperature program was: initial temperature, $120^{\circ} \mathrm{C}$ (8 minute) followed by $15^{\circ} \mathrm{C} /$ minute up to $160^{\circ} \mathrm{C}$ (zero minute), $4{ }^{\circ} \mathrm{C} /$ minute up to $195{ }^{\circ} \mathrm{C}$ (12 minute), and $10{ }^{\circ} \mathrm{C} /$ minute up to the final temperature of $230^{\circ} \mathrm{C}$ (25 minute); injector and detector temperatures $280{ }^{\circ} \mathrm{C}$. The equipment used hydrogen as carrier gas at a flow rate of $1 \mathrm{~mL} /$ minute and nitrogen as the make-up gas at $30 \mathrm{~mL} /$ minute. Retention times of FAME standards were used to identify chromatographic peaks of the samples. The fatty acid contents were calculated using the nonadecanoic methyl ester as the internal standard.

Cholesterol and cholesterol oxides were determined simultaneously (SALDANHA et al., 2006) and extracted as follows: in a flask with screw cap $(70 \mathrm{~mL}$, previously dried with $\mathrm{N}_{2}$ to prevent the formation of artifacts), a sample weighing $2 \mathrm{~g}$ was treated with a $4 \mathrm{~mL}$ of a $50 \%$ aqueous solution of $\mathrm{KOH}$ plus $6 \mathrm{~mL}$ of ethanol to perform saponification at room temperature for 22 hours in the dark. For the extraction of the unsaponifiable matter, $5 \mathrm{~mL}$ of distilled water and $10 \mathrm{~mL}$ of hexane were added to the samples, which were then shaken and the hexane fraction was separated. The extraction with $10 \mathrm{~mL}$ of hexane was repeated three times (total of 4 extractions). Subsequently, the solution was dried in a rotary evaporator (Tecnalise, Sao Paulo, SP, Brazil). The residue was dissolved in $5 \mathrm{~mL}$ of hexane, transferred to a screw top flask, dried under $\mathrm{N}_{2}$, diluted with $1 \mathrm{~mL}$ of mobile phase, filtered through a $22 \mu \mathrm{m}$ filter (Millipore, Maryland, MD, USA), and injected into the HPLC system (SALDANHA et al., 2006).

HPLC-UV-IR analysis was carried out on a Shimadzu liquid chromatograph (Kyoto, Japan) equipped with on-line UV-visible (SPD-10 $\mathrm{AV}_{\mathrm{vP}}$ ) and refractive index (RID-10AV $\left.\mathrm{vP}\right)$ detectors, rheodyne injector with a $20 \mu \mathrm{L}$ loop, a tertiary solvent delivery system $\left(\mathrm{LC}-10_{\mathrm{vp}}\right)$, oven heated column at $32{ }^{\circ} \mathrm{C}\left(\mathrm{CTO}-10_{\mathrm{vp}}\right)$, and a computer software (CLASS LC-10). The chromatography separation was achieved on a $4 \mu \mathrm{m}$ Nova Pack CN HP $(300 \times 3.9 \mathrm{~mm}$, Waters, Milford, MA, USA) normal-phase column, preceded by a $4 \mu \mathrm{m}$ Hypersil BDS CN $(7.5 \times 4.6 \mathrm{~mm}$, Alltech, Deerfield, IL, USA $)$ guard column according to procedures and conditions previously reported (SALDANHA et al., 2006). The mobile-phase was $n$-hexane:2-propanol $(97: 3, \mathrm{v} / \mathrm{v})$ at a flow rate of $1 \mathrm{~mL} /$ minute and an analysis time of 30 minutes.

The quantification was done by external standardization with a concentration range from 0.3 to $70 \mu \mathrm{g} \cdot \mathrm{mL}^{-1}$ for the oxides and from 0.2 to $1.8 \mathrm{mg} \cdot \mathrm{mL}^{-1}$ for the cholesterol. In order to confirm the identity of cholesterol and cholesterol oxides in the sardine samples, these samples were analyzed using HPLC with atmospheric pressure chemical ionization mass spectrometry (HPLC-APCI-MS). The mass spectrometer used was a Qtrap (Applied Biosystems, Concord, Ontario, Canada) with a QqQ 
(linear ion trap) configuration (SALDANHA et al., 2006). The cholesterol and epimeric 5.6 epoxides were identified using a refractive index detector for two reasons: better resolution of cholesterol and because the epoxides do not absorb at UV wavelengths. The other oxides were quantified using an UV detector at $210 \mathrm{~nm}$. The detection limits (signal-to-noise ratio of 3) were $0.04 \mu \mathrm{g} . \mathrm{g}^{-1}$ for $19-\mathrm{OH}$ and $20 \alpha-\mathrm{OH} ; 0.06 \mu \mathrm{g} \cdot \mathrm{g}^{-1}$ for $22(\mathrm{R})-\mathrm{OH}, 24(\mathrm{~S})-\mathrm{OH}, 25(\mathrm{R})-\mathrm{OH}$ and $25-\mathrm{OH} ; 0.07 \mu \mathrm{g} \cdot \mathrm{g}^{-1}$ for $22(\mathrm{~S})-\mathrm{OH}, 7 \beta-\mathrm{OH}$ and $7 \alpha-\mathrm{OH} ; 0.01 \mu \mathrm{g} \cdot \mathrm{g}^{-1}$ for 7 -keto and cholesterol; and $0.18 \mu \mathrm{g} . \mathrm{g}^{-1}$ for epimeric 5,6 epoxides. The recovery varied between 95 to $103 \%$ for all cholesterol oxides.

\subsection{Statistical analysis}

All data were subjected to analysis of variance (ANOVA). The comparison of the means between raw and grilled fish was carried out by Tukey's multiple range tests with $\mathrm{P}<0.02$. Statistical analysis was performed using the Origin 5.0 for Windows.

\section{Results and discussion}

\subsection{Moisture, fat, and cholesterol contents}

Data of moisture, lipids, and cholesterol for the different fishes obtained in this study are shown in Table 1.

The moisture contents of the raw fishes were found to be $81.3 \pm 2.0$ in sardine and $79.4 \pm 0.2 \mathrm{~g} .100 \mathrm{~g}^{-1}$ in hake. Similar levels were found in the grilled fishes: $72.1 \pm 1.0$ in sardine and $71.8 \pm 0.5 \mathrm{~g} .100 \mathrm{~g}^{-1}$ in hake samples. The results revealed that the total lipids varied between $7.7 \pm 0.7$ and $9.2 \pm 0.2 \mathrm{~g} .100 \mathrm{~g}^{-1}$ (dry weight basis) for both raw and grilled fishes. After grilling, significant differences $(p<0.02)$ were observed only in hake. The values obtained in the present study were similar to other studies of the same authors (SALDANHA; BRAGAGNOLO, 2007, 2008; SALDANHA; BENASSI; BRAGAGNOLO, 2008) and to the study of Méndez and González (1997), but they were lower than the observed by Luzia et al. (2003). Nowadays it is known that the lipid components of fish can vary according to the month of capture, the season, and the particular area of the sea. The mean values of cholesterol content were $214 \pm 2$ and $327 \pm 3 \mathrm{mg} .100 \mathrm{~g}^{-1}$ (dry weight basis) in the raw and grilled fishes. Higher values were determined in sardine samples. Grilling affected the cholesterol by causing a significant decrease in the evaluated fishes, similar to that found in other studies (MÉNDEZ; GONZÁLEZ, 1997; OHSHIMA et al., 1996; OHSHIMA, 2002,

Table 1. Moisture (g.100 g $\mathrm{g}^{-1}$ ), total lipid (g.100 $\mathrm{g}^{-1}$ dry basis) and cholesterol (mg.100 g $\mathrm{g}^{-1}$ dry basis) levels in raw and grilled sardine and hake samples.

\begin{tabular}{|c|c|c|c|c|}
\hline & \multicolumn{2}{|c|}{ Sardine } & \multicolumn{2}{|c|}{ Hake } \\
\hline & Raw & Grilled & Raw & Grilled \\
\hline Moisture & $81.30 \pm 2.0^{\mathrm{A}}$ & $72.10 \pm 1^{\mathrm{B}}$ & $79.40 \pm 0.2^{\mathrm{a}}$ & $71.80 \pm 0.5^{b}$ \\
\hline Total lipids & $8.50 \pm 0.6^{\mathrm{A}}$ & $8.00 \pm 0.7^{\mathrm{A}}$ & $9.15 \pm 0.2^{\mathrm{a}}$ & $7.70 \pm 0.7^{\mathrm{b}}$ \\
\hline Cholesterol & $327.00 \pm 2.7^{\mathrm{A}}$ & $253.00 \pm 2.0^{\mathrm{B}}$ & $249.30 \pm 0.9^{\mathrm{a}}$ & $214.00 \pm 2.2^{\mathrm{b}}$ \\
\hline $\begin{array}{l}\mathrm{A}, \mathrm{B} \text { Mean and } \\
\text { batches in dup } \\
\text { in hake (two b } \\
(\mathrm{p}>0.02) \text {. }\end{array}$ & $\begin{array}{l}\text { elative standard } \\
\text { licate); } a, b \text { Mean an } \\
\text { tches in duplicate }\end{array}$ & $\begin{array}{l}\text { eviation (RSD) o } \\
\text { relative standard }\end{array}$ & $\begin{array}{l}\text { the four analyses } \\
\text { leviation (RSD) of } \\
\text { ame letter do not }\end{array}$ & $\begin{array}{l}\text { in sardine (two } \\
\text { the four analyses } \\
\text { iffer significantly }\end{array}$ \\
\hline
\end{tabular}

OSADA et al., 1993; SALDANHA; BRAGAGNOLO, 2007, 2008; SALDANHA; BENASSI; BRAGAGNOLO, 2008).

\subsection{Fatty acid composition}

Table 2 shows the fatty acid contents in raw and grilled sardine and hake samples reported as g. $100 \mathrm{~g}^{-1}$ of the oil, as well as the total amount of saturated fatty acids (SFA), monounsaturated fatty acids (MUFA), and polyunsaturated fatty acids (PUFA).

Sardines and hake had similar fatty acid patterns. The main fatty acids found in all of the analyzed fishes were docosahexaenoic (DHA, 22:6n3), oleic (18:1), palmitic (16:0), and eicosapentaenoic (EPA, 20:5n3). The fatty acids profile was quite similar to the data reported by other authors in sardine (CANDELA; ASTIASÁRAN; BELLO, 1997, 1998; GARCÍA-ARIAS et al., 2003; SALDANHA; BENASSI; BRAGAGNOLO, 2008), and hake samples (CANDELA; ASTIASÁRAN; BELLO, 1997; MÉNDEZ; GONZÁLEZ, 1997; SALDANHA; BRAGAGNOLO, 2007, 2008.

In the raw samples the SFA, MUFA, and PUFA accounted for approximately 16,21 , and $38 \mathrm{~g} .100 \mathrm{~g} \mathrm{~g}^{-1}$ in sardine, respectively,

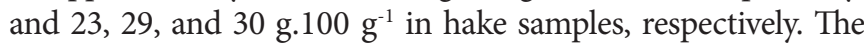
DHA and EPA were the predominant PUFA accounting for 16.7-18 and 6.4-11.4 g.100 g ${ }^{-1}$, respectively, of the total FA for the two fish species.

The amount of $\omega 3$ polyunsaturated fatty acids in the raw sardines $\left(30.18 \pm 0.2 \mathrm{~g} .100 \mathrm{~g}^{-1}\right)$ and hake $\left(25.42 \pm 0.3 \mathrm{~g} .100 \mathrm{~g}^{-1}\right)$ were much higher than $\omega 6\left(7.97 \pm 0.2\right.$ in sardine and $4.70 \pm 0.1 \mathrm{~g}^{1} 100 \mathrm{~g}^{-1}$ in hake). As referred in previous research reports, marine fishes contain higher amounts of $\omega 3$ than $\omega 6$ fatty acids, fact that has been connected, among other factors, to the type of their diet, which varies in different marine regions (LAVANIEGOS; LOPEZ-CORTES, 1997).

Significant differences $(\mathrm{p}<0.02)$ in the total amount of SFA, MUFA, and PUFA were observed among the raw and grilled fishes. Grilling the fishes resulted in a decrease in the total amount of fatty acids in the order of $14.6 \%$ in sardine and $15.2 \%$ in hake. The content of EPA and DHA after grilling was significantly reduced in the range of 16.2 to $31.8 \%$ in EPA and 21.6 to $28.3 \%$ in DHA. Unsaturated fatty acids are far more heat-labile since their instability increases with the degree of unsaturation. In the presence of oxygen, PUFA degradation occurs more readily and undergoes pronounced oxidative effects (LITTLE; ARMSTRONG; BERGAN, 2000). PUFA contents in aquatic species were demonstrated to decrease after heat treatment (CANDELA; ASTIASÁRAN; BELLO, 1997; OHSHIMA et al., 1996; SALDANHA; BRAGAGNOLO, 2007, 2008; SALDANHA; BENASSI; BRAGAGNOLO, 2008).

Possible mechanisms for the changes occurring in the heat treatment are the leaching of fat-soluble molecules out of the food and oxidation reactions (LITTLE; ARMSTRONG; BERGAN, 2000). These mechanisms are also responsible for the changes in the fat and cholesterol.

Although many authors estimate the potential nutritive value of fishes on the basis of per cent content of PUFA, it would be better to draw such conclusions using mass units, 
Table 2. Fatty acids composition (g.100 $\mathrm{g}^{-1}$ of oil) in raw and grilled sardine and hake samples.

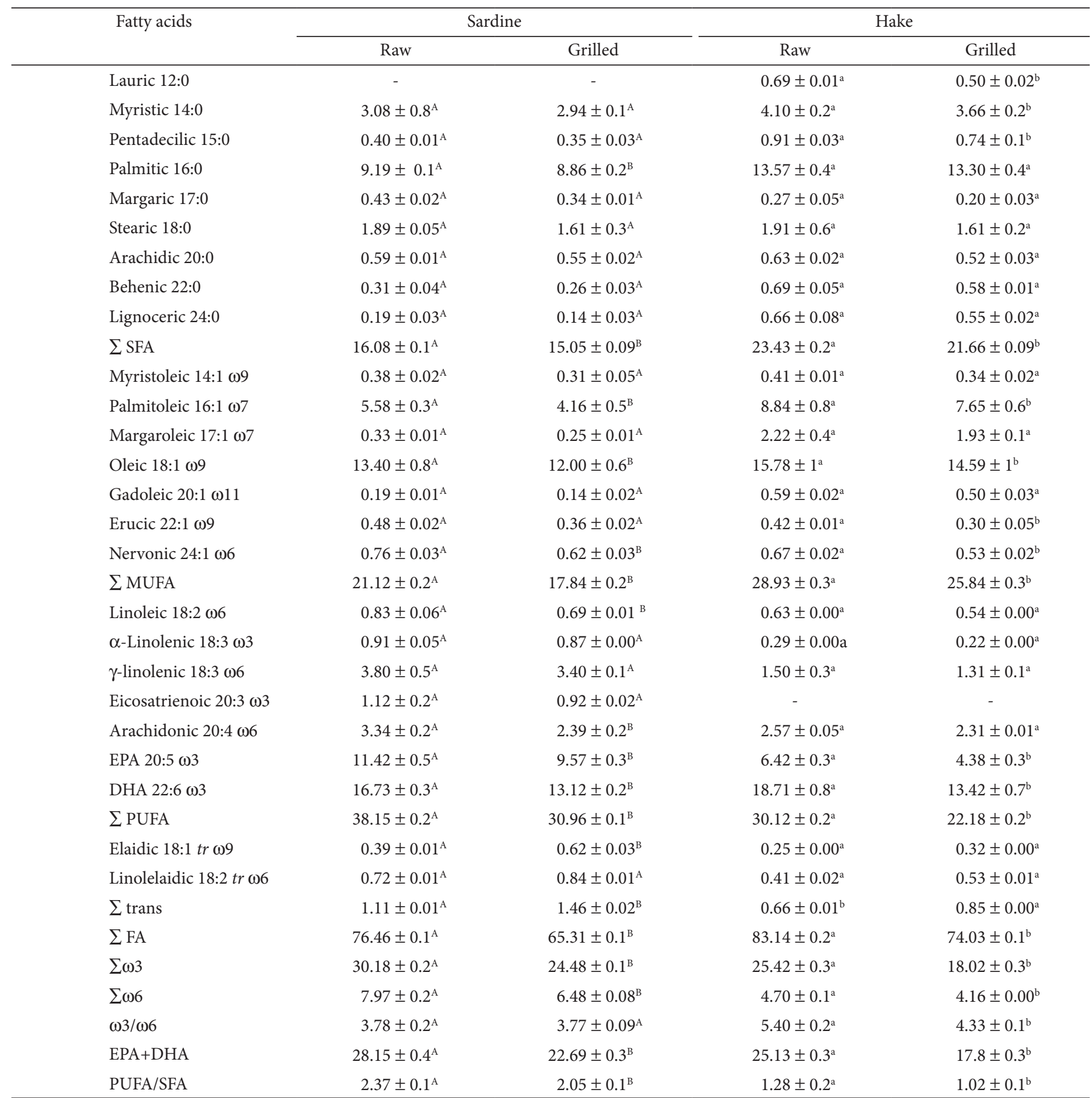

${ }_{\mathrm{A}, \mathrm{B}}$ Mean and relative standard deviation (RSD) of the four analyses in sardine (two batches in duplicate); ${ }^{\mathrm{a}, \mathrm{b}}$ Mean and relative standard deviation (RSD) of the four analyses in hake (two batches in duplicate); and means in the same letter do not differ significantly $(\mathrm{p}>0.02)$.

e.g., quantity of $\mathrm{EPA}+\mathrm{DHA}$ content in a fish dish, or, in the other words, the quantity of fish dish to be consumed by a individual to obtain the daily quantity of the two essential PUFA recommended by WHO (GLADYSHEV et al., 2007), which is $1 \mathrm{~g}$ per day. The grilled fishes contained between 0.5 and $0.39 \mathrm{~g} \mathrm{EPA}+\mathrm{DHA} .100 \mathrm{~g}^{-1}$ product. Thus, our results indicate that consuming approximately $180 \mathrm{~g}$ of sardine or $260 \mathrm{~g}$ hake daily would be sufficient to obtain the recommended amount of EPA+DHA.

The $\omega 3 / \omega 6$ ratio in the raw and grilled fishes varied from 3.77 and 5.40, and according to current WHO recommendations, the daily ratio $\omega 3 / \omega 6$ in total human diet should be no higher than 0.2 (VUJKOVIC et al., 1999). The values found in the present study are higher than the recommended values, but it 
should be taken into account that in most part of other foods the $\omega 3 / \omega 6$ ratio is lower than necessary.

\subsection{Cholesterol oxides}

The cholesterol oxide contents, calculated on a dry weight basis are shown in Table 3. Two oxides, 7-keto and 19-OH were originated from the main chain and four, $24(\mathrm{~S})-\mathrm{OH}, 22(\mathrm{~S})-\mathrm{OH}$, $25(\mathrm{R})-\mathrm{OH}$, and $25-\mathrm{OH}$, from the side chain. Similar results were reported in other studies by the same authors (SALDANHA; BRAGAGNOLO, 2007, 2008; SALDANHA; BENASSI; BRAGAGNOLO, 2008)

Nevertheless, in many previous studies (OHSHIMA et al., 1996; OHSHIMA, 2002; TAI; CHEN; CHEN, 2000) it was reported that 7 -keto, $7 \beta-\mathrm{OH}, 7 \alpha-\mathrm{OH}$, and the epimeric epoxides were predominant in the total of COP in fish and $25-\mathrm{OH}$ was the only side chain $\mathrm{COP}$ found in seafood products (OHSHIMA, 2002). Even so, under the chromatographic conditions used in the present study, it was possible to separate and to identify a large number of oxides originated from the oxidation of lateral chain, which are normally not determined in food products.

The raw sardine samples showed higher total oxide amounts $\left(20.62 \pm 0.4 \mu \mathrm{g} . \mathrm{g}^{-1}\right)$ than those of the hake samples $\left(8.79 \pm 1.3 \mu \mathrm{g} . \mathrm{g}^{-1}\right)$, and the amounts of COP found in the different analysed samples were probably correlated with a remarkable differences in the chemical composition, mainly cholesterol and total of PUFA contents among the fish species. This difference depends on several factors including the region and the season of fishery and sex and age of the fish (LUZIA et al., 2003).

19-hydroxycholesterol was the main contributor of COP in the raw sardine samples, being the most abundant fraction in these fish $\left(15.18 \pm 1.2 \mu \mathrm{g} . \mathrm{g}^{-1}\right)$. In the raw hake samples, higher content of $25-\mathrm{OH}\left(4.49 \pm 0.2 \mu \mathrm{g} . \mathrm{g}^{-1}\right)$ followed by 19-hydroxycholesterol $\left(2.16 \pm 0.1 \mu \mathrm{g} \cdot \mathrm{g}^{-1}\right)$ was observed. The origin of the $19-\mathrm{OH}$ in food systems has not been elucidated although in many studies this oxide was found in mutton meat (KOWALE et al., 1996), buffalo meat (RAO et al., 1996) and fish samples (SALDANHA; BRAGAGNOLO, 2007; SALDANHA; BRAGAGNOLO, 2008; SALDANHA; BENASSI;

Table 3. Cholesterol oxides levels ( $\mu \mathrm{g} \cdot \mathrm{g}^{-1}$, dry basis) in raw and grilled sardine and hake samples.

\begin{tabular}{lccccc}
\hline \multirow{2}{*}{ COPs } & \multicolumn{2}{c}{ Sardine } & & \multicolumn{2}{c}{ Hake } \\
\cline { 2 - 3 } \cline { 5 - 6 } & \multicolumn{2}{c}{ Raw } & Grilled & Raw & Grilled \\
\hline $19-\mathrm{OH}$ & $15.18 \pm 1.2^{\mathrm{B}}$ & $27.69 \pm 1.3^{\mathrm{A}}$ & & $2.16 \pm 0.1^{\mathrm{b}}$ & $3.84 \pm 0.3^{\mathrm{a}}$ \\
$24(\mathrm{~S})-\mathrm{OH}$ & $1.24 \pm 0.2^{\mathrm{B}}$ & $3.45 \pm 0.6^{\mathrm{A}}$ & & $0.37 \pm 0.03^{\mathrm{b}}$ & $1.19 \pm 0.1^{\mathrm{a}}$ \\
$22(\mathrm{~S})-\mathrm{OH}$ & $1.37 \pm 0.3^{\mathrm{B}}$ & $2.29 \pm 0.6^{\mathrm{A}}$ & & $0.96 \pm 0.05^{\mathrm{b}}$ & $1.53 \pm 0.7^{\mathrm{a}}$ \\
$25-\mathrm{OH}$ & $1.17 \pm 0.2^{\mathrm{B}}$ & $6.48 \pm 0.1^{\mathrm{A}}$ & & $4.49 \pm 0.2^{\mathrm{b}}$ & $10.84 \pm 1.0^{\mathrm{a}}$ \\
25(R)-OH & $0.35 \pm 0.04^{\mathrm{B}}$ & $0.69 \pm 0.01^{\mathrm{A}}$ & & $0.81 \pm 0.01^{\mathrm{b}}$ & $1.29 \pm 0.3^{\mathrm{a}}$ \\
7-keto & $1.31 \pm 0.6^{\mathrm{B}}$ & $2.68 \pm 0.3^{\mathrm{A}}$ & - & $0.66 \pm 0.1^{\mathrm{a}}$ \\
Total & $20.62 \pm 0.4^{\mathrm{B}}$ & $43.28 \pm 0.4^{\mathrm{A}}$ & $8.79 \pm 0.1^{\mathrm{b}}$ & $19.35 \pm 0.4^{\mathrm{a}}$ \\
\hline
\end{tabular}

${ }^{\mathrm{A}, \mathrm{B}}$ Mean and relative standard deviation (RSD) of the four analyses in sardine (two batches in duplicate); ${ }^{\mathrm{a}, \mathrm{b}}$ Mean and relative standard deviation (RSD) of the four analyses in hake (two batches in duplicate); means in the same letter do not differ significantly $(\mathrm{p}>0.02)$.
BRAGAGNOLO, 2008) Either the metabolic production in fish or the proximity of position 19 with double bound between $\mathrm{C}_{5}$ and $\mathrm{C}_{6}$ making the $\mathrm{C}_{19}$ more susceptible to the attack of the peroxyl radicals could be considered two likely ways for the formation of this oxide.

The formation of cholesterol oxidation products increased significantly $(\mathrm{p}<0.02)$ after grilling for all samples evaluated. The increase of total oxides was about 110 and $120 \%$ for sardine and hake, respectively. The most affected oxides by the heat treatment were the $25-\mathrm{OH}$ and $24(\mathrm{~S})-\mathrm{OH}$ in both samples. Normally, in food systems the major oxide found is 7-keto, which is also considered an indicative of oxidation. However, in this study, 7-keto was not observed in the fresh hake, only in the grilled samples. Heat oxidation in cholesterol rich food systems is a dynamic reaction (KIM; NAVAR, 1991; NAVAR et al., 1991), which depends on the amount of cholesterol present, the type and severity of the heat treatment, and the presence of free radicals in the sample. Several studies on the generation of COP during heat treatment of fish have been published (AL-SAGHIR et al., 2004; OHSHIMA, 2002; SAMPAIO et al., 2006), and many COP formations through grilling have been reported (OHSHIMA et al., 1996; SALDANHA; BRAGAGNOLO, 2007, 2008; SALDANHA; BENASSI; BRAGAGNOLO, 2008; SHOZEN et al., 1995). The nature, proportion, and degree of unsaturation of fatty acids present in fish product systems will indicate the approximate susceptibility of those products to oxidative deterioration. According to Al-Saghir et al., (2004) the higher degree of unsaturation, the higher the lipid oxidative process, and the more COP are formed. The COPs are formed in the majority of processed foods containing cholesterol, and heating is one of the major causes of their synthesis (TAI; CHEN; CHEN, 2000). Considering the amounts of PUFA found in the fresh fishes studied and the temperature of grilling, the increase of oxides formation after thermal treatment can be justified.

\section{Conclusion}

It is evident from a consideration of the results obtained in this study that the oxidation of cholesterol was stimulated by the presence of PUFA and that grilling favored the COP formation. The samples of sardine and hake showed great polyunsaturated fatty acids levels, and these results indicate that consuming approximately $180 \mathrm{~g}$ of sardine or $260 \mathrm{~g}$ hake daily is sufficient to obtain the recommended amount of EPA+DHA. However, higher amounts of COP were formed. In addition, a more systematic analysis of heated fishes is necessary since there is a trend in the consumption of fish due the positive effects of its long chain PUFA regarding cardiovascular diseases. The physiological implication of ingesting COP also deserves further studies.

\section{Acknowledgments}

The authors are grateful for the financial support provided by the foundations FAPESP (The State of São Paulo Research Foundation), CAPES (Brazilian research supporting foundation), and $\mathrm{CNPq}$ (The National Council for Scientific and Technological Development). 


\section{References}

AL-SAGHIR, S. et al. Effects of different cooking procedures on lipid quality and cholesterol oxidation of farmed salmon fish (Salmo salar). Journal of Agricultural and Food Chemistry, v. 52, n. 16, p. 5290-5296, 2004.

ASSOCIATION OF OFFICIAL ANALYTICAL CHEMISTS - AOAC. Official methods of analysis. 17 ed. Washington, 2000.

BLIGH, E.; DYER, W. A rapid method of total lipid extraction and purification. Canadian Journal of Biochemistry and Physiology, v. 37, n. 8, p. 911-917, 1959.

CANDELA, M.; ASTIASÁRAN, I.; BELLO, J. Effects of frying and warmholding on fatty acids and cholesterol of sole (Solea solea), codfish (Gadus morrhua) and hake (Merluccius merluccius). Food Chemistry, v. 58, n. 3, p. 227-231, 1997.

CANDELA, M.; ASTIASÁRAN, I.; BELLO, J. Deep-fat frying modifies high-fat fish lipid fraction. Journal of Agricultural and Food Chemistry, v. 46, n. 7, p. 2793-2796, 1998.

DIN, J. N.; NEWBY, D. E.; FLAPAN, A. D. Science, medicine, and the future - Omega 3 fatty acids and cardiovascular disease - fishing for a natural treatment. British Medical Journal, v. 328, n. 7430, p. 30-35, 2004.

GARCÍA-ARIAS, M. T. et al. Grilling of sardine fillets: effects of frozen and thawed modality on their protein quality. LWT - Food Science and Technology, v. 36, n. 8, p. 763-769, 2003.

GLADYSHEV, M. I. et al. Effect of boiling and frying on the content of essential polyunsaturated fatty acids in muscle tissue of four fish species. Food Chemistry, v. 101, n. 4, p. 1694-1700, 2007.

HUR, S. J.; PARK, G. B.; JOO, S. T. Formation of cholesterol oxidation products (COPs) in animal products. Food Control, v. 18, n. 8, p. 939-947, 2007.

JOSEPH, J. D.; ACKMAN, R. G. Capillary column gas-chromatographic method for analysis of encapsulated fish oil and fish oil ethyl-esters: collaborative study. Journal of AOAC International, v. 75, n. 3, p. 488-506, 1992.

KIM, S. K.; NAWAR, W. W. Oxidative interactions of cholesterol with triacylglycerols. Journal of the American Oil Chemistry Society, v. 68, n. 12, p. 931-934, 1991.

KOWALE, B. N. et al. Lipid oxidation and cholesterol oxidation in mutton during cooking and storage. Meat Science, v. 43, n. 2, p. 195-202, 1996.

LAVANIEGOS, E.; LOPEZ-CORTES, D. Fatty acid composition and community structure of plankton from the San Loranzo Channel, Gulf of California. Estuarine Coastal and Shelf Science, v. 45, n. 6, p. 845-854, 1997.

LITTLE, S. O.; ARMSTRONG, S. G.; BERGAN, J. G. Factors affecting stability and nutritive value of fatty acids: culinary practices. In: CHOW, C. K. (Ed.). Fatty acids in foods and their health implications. New York: CRC Press, 2000. p. 427-437.

LUZIA, L. A. et al. The influence of season on the lipid profiles of five commercially important species of Brazilian fish. Food Chemistry, v. 83, n. 1, 93-97, 2003.
MÉNDEZ, E.; GONZÁLEZ, R. M. Seasonal changes in the chemical and lipid composition of fillets of the Southwest Atlantic hake (Merluccius hubbsi). Food Chemistry, v. 59, n. 2, p. 213-217, 1997.

NAVAR, W. W. et al. Measurement of oxidative interactions of cholesterol. Journal of the American Oil Chemists Society, v. 68, n. 7, p. 496-498, 1991.

OHSHIMA, T. et al. Effects of grilling on formation of cholesterol oxides in seafood products rich in polyunsaturated fatty acids. LWT - Food Science Technolology, v. 29, n. 1-2, p. 94-99, 1996.

OHSHIMA, T. Formation and content of cholesterol oxidation products in seafood and seafood products. In: GUARDIOLA, F. et al. (Eds.). Cholesterol and phytosterol oxidation products in foods and biological samples: analysis, occurrence and biological effects. New York: AOAC Press, 2002. p. 187-203.

OSADA, K. et al. Levels and formation of oxidized cholesterols in processed marine foods. Journal of Agricultural and Food Chemistry, v. 41, n. 11, p. 1893-1898, 1993.

RAO, V. K. et al. Effect of cooking and storage in lipid oxidation and development of cholesterol oxidation products in water buffalo meat. Meat Science, v. 43, n. 2, p. 179-185, 1996.

SALDANHA, T. et al. HPLC separation and determination of 12 cholesterol oxidation products in fish: comparative study of RI, UV and APCI-MS detectors. Journal of Agricultural and Food Chemistry, v. 54, n. 12, p. 4107-4113, 2006.

SALDANHA, T.; BRAGAGNOLO, N. Cholesterol oxidation is increased and PUFA decreased by frozen storage and grilling of Atlantic hake fillets (Merluccius hubbsi). Lipids, v. 42, n. 7, p. 671-678, 2007.

SALDANHA, T.; BRAGAGNOLO, N. Relation between types of packaging, frozen storage and grilling on cholesterol and fatty acids oxidation in Atlantic hake fillets (Merluccius hubbsi). Food Chemistry, v. 106, n. 2, p. 619-627, 2008.

SALDANHA, T.; BENASSI, M. C.; BRAGAGNOLO, N. Fatty acid contents evolution and cholesterol oxides formation in Brazilian sardines (Sardinella brasiliensis) as a result of frozen storage followed by grilling. LWT - Food Science and Technology, v. 41, n. 7, p. 1301-1309, 2008.

SAMPAIO, G. R. et al. Fatty acids and cholesterol oxidation in salted and dried shrimp. Food Chemistry, v. 95, n. 2, p. 344-351, 2006.

SCHROEPFER, G. J. Oxysterols: modulators of cholesterol metabolism and other processes. Physiological Reviews, v. 80, n. 1, p. 361-554, 2000 .

SHOZEN, K. et al. Formation of cholesterol oxides in marine fish products induced by grilling. Fisheries Science, v. 61, n. 5, p. 817-821, 1995.

TAI, C. Y.; CHEN, Y. C.; CHEN, B. H. Analysis, formation and inhibition of cholesterol oxidation products in foods: an overview. Journal of Food and Drug Analysis, v. 8, n. 1, p. 1-15, 2000. (part II)

VUJKOVIC, G. et al. Composition of muscle tissue lipids of silver carp and bighead carp. Journal of the American Oil Chemists Society, v. 76, n. 4 , p. $475-480,1999$. 